\title{
THE ARGUMENTATIVE STRUCTURE OF SPATIAL DATA INFRASTRUCTURE INITIATIVES IN AMERICA AND AFRICA
}

\author{
Yola Georgiadou \\ International Institute for Geo-Information Science and Earth Observation (ITC), \\ The Netherlands \\ Vincent Homburg \\ Erasmus Universiteit Rotterdam FSW, The Netherlands
}

\begin{abstract}
Policy, including technology policy, is made of language. Politicians, bureaucrats, and consultants use language to shape action and ways of thinking by fabricating rules that enable individuals to deal with unresolvable contradictions of everyday life. The evolution of geospatial ICT policy can be best understood through the language of spatial data infrastructure (SDI) initiatives and the analysis of their argumentative structure. We focus on how SDI has been rhetorically crafted over almost two decades and how the rhetoric ("myth") unfolds as SDI myths move from one context (North America) to the other (Africa). We conclude that despite apparent similarities, there are durable differences. In the American myth, there is a clamour for "metrics" which can demonstrate progress and knowledge generation through research. In the African context, a rhetorical move is made by aligning the SDI concept with overarching Information Society concepts as promoted by the African Information Society Initiative (AISI). We suggest further research directions to explore how ICT policy talk interacts with the context in which it takes shape as it travels in space and time.
\end{abstract}

Keywords: Spatial data infrastructure, rhetoric, ICTs in developing countries

\section{Introduction}

Spatial data infrastructure (SDI) refers to the assembly of geospatial technologies and institutional arrangements and practices that allow for the disclosure and sharing of geospatial data among various levels of government, citizens, and corporations. Spatial data infrastructure (SDI) doctrines, such as "data should be collected at one level of government and shared between all levels", "it should be possible to combine seamlessly data from different sources

Please use the following format when citing this chapter:

Georgiadou, Y. and Homburg, V., 2008, in IFIP International Federation for Information Processing, Volume 282; Social Dimensions of Information and Communication Technology Policy; Chrisanthi Avgerou, Matthew L. Smith, Peter van den Besselaar; (Boston: Springer), pp. 31-44. 
and share it between many users and applications" etc., underpin geospatial ICT policy, for example, in the European Union [13].

Geospatial ICT caught the imagination of American think tanks in the early years of the Clinton-Gore administration when complex and distributed information systems were re-conceptualized as information infrastructure (II). Similarly, geographical information systems, dealing with geospatial data, were also becoming more complex and distributed, and re-conceptualized as a spatial data infrastructure (SDI). A national II was expected to provide for the integration of hardware, software, and skills to make it easy and affordable to connect people with each other, with computers, and with a vast array of services and information resources [39], while the purpose of a national SDI was to advance the goals of a national II by avoiding wasteful duplication of governmental geospatial data and resources [40].

In the early days, SDI initiatives were phrased primarily in terms of economic considerations of sharing capital-intensive and basic geospatial data "among the widest possible group of potential users at affordable costs" [40, p. 2]. National II and SDI initiatives were frequently phrased in those days as information superhighways emphasizing predictability, procedures and efficiency of delivery, technical access guided by the needs of commerce and government, a key role for central government in directing a top-down construction of the information superhighway, and the assumption of harmonious collaboration between governmental agencies. Contemporary discourse now recognizes II and SDI also as strategic infrastructures for social progress, particularly in supranational settings.

In this chapter, we focus on SDI talk as a more or less persuasive doctrine [12] or myth [21]: a statement of intention towards some part of a target audience, where the intention is that the "myth" serves as (1) a common frame of reference that experts, administrators, and politicians use to enact social reality, (2) a link between argument and acceptance, and (3) a source of inspiration that guides a specific course of action. Bearing in mind the observation that technological and managerial "ideas" often travel [8] over space and time as they are rhetorically crafted, the research objective of this chapter is then to analyze and critically examine the myths that underlie SDI initiatives as they mutate while travelling from distant think tanks to various real world settings [8].

The remainder of the chapter is organized as follows. In section two, we define SDI talk as myth and outline the research strategy. In section three, we analyze and reflect upon the changing argumentative structure in the American and African SDI myths over space and time. Section four summarises preliminary conclusions and directions for future research.

\section{The language of SDI initiatives}

SDI became stabilized as a concept in 1993 in a report commissioned by the United States National Research Council [28]. One of the contributing authors of 
this report, Prof. John McLaughlin, had coined the term in two influential key note speeches, delivered in 1991 first to a Canadian [20] and then to an Australian audience [19]. Ever since, the notion of a spatial data infrastructure (SDI) has been discussed intensively in think tanks populated by geospatial academics, as well as by practitioners, software vendors, and policy makers. Since its official American début in 1993, the concept has been expanded in the United States in a series of National Research Council reports [22-30], and picked up in other contexts such as India [9], the European Union [18], and in a series of global spatial data infrastructure conferences (GSDI). Concurrently, throughout the 1990s, various national governments (Australia, United States, Qatar, Portugal, the Netherlands, Indonesia, Korea, Japan, and the United Kingdom, to name a few examples) pioneered implementation of national SDIs.

In 2001, a position paper of the Economic Commission of Africa (ECA), titled The Future Orientation of Geoinformation Activities in Africa, and prepared under the guidance of Prof. John McLaughlin, signalled the official arrival of the SDI concept in Africa [3]. By that time, ECA's prestigious African Information Society Initiative (AISI): An Action Framework to Build Africa's Information and Communication Infrastructure was already in full swing of implementation but largely oblivious of geospatial ICT [38].

\subsection{Myths as inspiring tales}

Following Mosco [21], we define myths as hymns to progress, and as utopian visions or promises unfulfilled or even unfulfillable. Myths are composed by socalled bricoleurs [15]: experts, politicians, bureaucrats and consultants who, in language, attempt to fabricate rules that serve as a shared frame of reference that enables individuals and organisations to deal with contradictions that can never be fully resolved [15-17], eventually enabling the bricoleur to inflict changes in ways of thinking and doing.

Myths have a number of recurrent features: they often are ubiquitous, usually rest on soft data (selectively drawn examples) and soft logic (use of persuasive example), they "win" over competing ideas by persuasion in communicative processes rather than by hard factual evidence, and often are contradictory and unstable (susceptible to new styles, fashions, and fads). The act of persuasion commonly involves the correct choice of metaphor, which taps into or builds shared modes of thinking. An example of the use of metaphors in the global SDI discourse is the use of imagery of physical infrastructures in relation to geospatial databases [11].

The notion of myth has been fruitfully theorized about and applied in discursive approaches within policy sciences [10]. For instance Hood and Jackson [12] identified 99 "doctrines" of administrative argument, and Bekkers and Homburg [2] identified four major "myths" in national e-government programs of Australia, the United Kingdom, the Netherlands, Denmark, and the United States. Smullen [35] analyzed public management reform accounts to identify and explain 
similarities and differences of administrative reforms in the Netherlands, Sweden, and Australia.

It is important at this moment to emphasize two issues. First, by referring to myths, in no way do we look down upon strenuous processes of SDI development. In this study we merely focus on argumentative structures of SDI initiatives. Second, unlike theories, myths are not testable, and debunking them is of little value. What is of interest is what myths represent, and how myths may or may not contribute to established bases of meaning and experiences with, in this case, spatial data infrastructures. As such, myths are neither true nor false, but either living or dead [16].

\subsection{Myths and context}

Although a focus on the language of ideas, myths, and argumentation may be interpreted as a move away from the operational particulars of everyday practice, myths cannot be separated from the context in which language takes shape. Ideas, embodied in myths, can simply not be isolated from the institutional context in which myths are crafted, used, and interpreted. The link between myth and its institutional context is that myths lend themselves to imitation: either appealing myths are copied from one context to the other, or a myth is copied from a wellknown, prestigious, global "template". In the context of public management reform, Sahlin-Andersson [34] has noted that ideas are edited as part of the imitative process; how myths are retold in specific countries, continents or institutional settings depends, in some unspecified way, on institutional context, for instance on which actors are privileged to speak, and the timing of the emergence of those privileged to speak. Sahlin-Andersson identifies two basic patterns related to imitation of ideas and practices throughout various institutional contexts. The first one is that imitative behaviour is natural when goals and technologies are ambiguous. The second one is that interests of international bodies are a source of widely held beliefs about what uses and technologies are appropriate [1, 34].

\subsection{A research strategy for analysis and comparison}

In the current research, we analyze SDIs as myths, with a special focus on how myths become domesticated across space and time. We focus on the time period between 1990 (when the notion of SDI was first explicitly used) and 2007, and attempt to reconstruct the transformatory journey of the SDI notion in the North American discourse, the way it was translated [24] in the sub-Saharan African discourse, and how it has subsequently travelled in the African discourse. The choice for Africa is based on the explicit reference to the translation from North America to the African Continent [24], but also on pragmatic grounds in the sense that one of the authors of this chapter actively participated in the African CODI conferences [3-7] in which the African SDI rhetoric actually took shape. 
More specifically, policy documents, research reports, and conference transcripts were gathered and subsequently scanned for discrete, unique utterances, inferences, and phrases within particular orders of discourse. Then, bearing in mind we were primarily interested in the mobilizing and persuasive qualities of myths, we reduced a larger set of utterances to specific higher level concepts. These concepts [see also 2, 12] are:

- How SDIs are defined and what metaphors were being used to describe them;

- What SDIs are supposed to do (ambitions: what is aimed for and how the results should be accomplished);

- Justification for action; and

- Perceived barriers that should be overcome.

Additionally, the analysis was informed by means of additional interview data with one key informant. The method as described above is susceptible to at least two forms of criticism. First and foremost, like any semiformal method involving identification and clustering of linguistic acts, this approach is inevitably subjective. Second, some readers may think the approach is too informal and actually does not deconstruct meaning or reveal hidden macro-level power structures. Those readers are reminded that the objective of this exercise was not to relate linguistic acts with overarching power structures, but rather to illuminate and identify the mobilizing potential of SDI myths. As such, in the analysis, the reinterpretation of SDI over time, in various policy documents and resolutions, has taken precedence over the in-depth (and very time-consuming) analysis of specific written or oral texts.

\section{Findings: African and American SDI "bricolage"}

\subsection{The American myth 1990-2007}

The American SDI myth takes shape in various documents of the National Research Council (NRC) [22-30]. By reading against the reports and documents from 1991 to 2007, it is hard to miss an overall mobilizing tone. Using metaphorical language, SDIs are described as physical infrastructure (1999-2007), information marketplaces (1991-1993), and (digital) commons (1999-2003), and are generally seen as opportunities that simply cannot be missed [26, p. 1, 2, 3, 6]. Once realized, SDIs are portrayed as mandatory for rationalized decision making, for instance for the promotion of public safety, fight against terrorist attacks, and dealing with contingencies. Barriers standing in the way of the inescapable technological sublime are uncertainty about policies and investments, and lack of incentives towards sharing of geospatial data (see Table 1 for a detailed analysis). SDI development is depicted as a rather technical game: existing geospatial databases are to be integrated into a network by following a nine step strategy [29, 
p. 116], so that eventually "[a]ccessing spatial data should become as easy as turning on a light switch" [29, p.112].

By 2001, accounts of meagre SDI progress [25], later on also signalled in a Congressional Hearing of the Committee on Government Reform, increased the reflexivity in the American rhetoric. In reports published in 2001 and beyond, NRC's abandonment of the evangelical tone of its previous documents, and a pragmatic turn is apparent in at least three ways.

- There is a clamour for the development of specific hypotheses regarding SDI goals [25] and a quest for demonstrating possibilities rather than promoting them, preferably using metrics to monitor long-term success in the adoption and principles of SDIs;

- It is argued that responsibility for developing a significantly more modest version of a national SDI for America, the so-called National Map, should be placed on a single federal government agency, the United States Geological Survey (USGS), which is furnished with a research agenda that provides the scientific underpinning for USGS operations [27]; and

- Although the abstract level of formulating ambitions is never really abandoned, specific attention is paid to more modest ambitions, and an eye for modesty in implementation: "all of these needs and applications must be balanced against the reality that $[. .$.$] it cannot be all things to all people$ and all applications [...] because this will generate unreasonable expectations and scepticism from data producers" [30, p. 127].

While the evangelical tone is forsaken in reports meant for an American audience, the 2002 NRC report Down to Earth: Geographic Information for sustainable development in Africa [24], despite addressing a heterogeneous African audience, resurrected the physical infrastructure rationale for investing in information infrastructure. Down to Earth was a component of the U.S. State Department's "geographic information for sustainable development" project for the world summit, focusing on sub-Saharan Africa. Down to Earth signalled that "...building infrastructure for geo[graphic] information use is becoming as important to African countries as the building of roads, telecommunication networks [...] The rationale for investing in information infrastructure is analogous to that for physical infrastructure" [19]. The report emphasizes that "[...] access to integrated geographic information allows civil society to hold government accountable; and government creates policies that determine public access to information and public participation in the decision process" [19]. It urges African countries and international development programs to consider using a standardized SDI, compatible with the emerging global spatial infrastructure, and conforming to the same standards, to achieve sustainable development. 


\begin{tabular}{|c|c|c|c|c|}
\hline Period & Metaphor & What is aimed for & Justification & Barriers \\
\hline $\begin{array}{l}1999- \\
2007\end{array}$ & $\begin{array}{l}\text { Physical } \\
\text { infrastruct- } \\
\text { ure or } \\
\text { building } \\
\text { construc-tion } \\
{[29, \text { p. 15] }}\end{array}$ & $\begin{array}{l}\text { Integrated databases } \\
\text { with information } \\
\text { about physical, social } \\
\text { and economic } \\
\text { geography that } \\
\text { provides linkages } \\
\text { between goverments, } \\
\text { citizens, and private } \\
\text { sector; } \\
\text { "Streamlined" [22,p. } \\
\text { 1] decision support } \\
\text { for societal problems } \\
\text { crossing functional } \\
\text { and geographical } \\
\text { boundaries [26] }\end{array}$ & $\begin{array}{l}\text { The upcoming information society } \\
\text { requires availability of geographic } \\
\text { information }[29, \text { p. 1] } \\
\text { Opportunity that simply cannot be } \\
\text { missed }[26, \text { p. } 1,2,3,6] \\
\text { Sunk costs of existing, localized } \\
\text { database; } \\
\text { SDI "will be an enormous benefit } \\
\text { to federal agencies, state and local } \\
\text { governments, the private sector, } \\
\text { and the public at large" }\end{array}$ & $\begin{array}{l}\text { Unclear policy and } \\
\text { social issues, for } \\
\text { instance debate about } \\
\text { access rights } \\
\text { Uncertainty about } \\
\text { impact of SDI } \\
\text { investments on } \\
\text { decision making } \\
\text { Skills and } \\
\text { competencies } \\
\text { Lack of incentives to } \\
\text { share data and } \\
\text { engage in } \\
\text { information } \\
\text { partnerships }\end{array}$ \\
\hline $\begin{array}{l}1991- \\
1993\end{array}$ & $\begin{array}{l}\text { Information } \\
\text { Market-place }\end{array}$ & $\begin{array}{l}\text { Supply of information } \\
\text { services critical to a } \\
\text { national competitive } \\
\text { position in a } \\
\text { globalizing economic } \\
\text { arena [29, p. 2] }\end{array}$ & $\begin{array}{l}\text { SDI is necessary for the } \\
\text { maintenance of competitive } \\
\text { position }\end{array}$ & $\begin{array}{l}\text { Traditional pricing } \\
\text { strategies for spatial } \\
\text { information products } \\
\text { (token prices) }\end{array}$ \\
\hline \multirow[t]{2}{*}{$\begin{array}{l}1999- \\
2003\end{array}$} & \multirow[t]{2}{*}{$\begin{array}{l}\text { Commons } \\
\text { [23] or Quilt } \\
{[30]}\end{array}$} & $\begin{array}{l}\text { Distributed geospatial } \\
\text { library from which } \\
\text { users can extract data } \\
\text { for own purposes, and } \\
\text { contribute locally } \\
\text { gathered resources to } \\
\text { common repositories } \\
\text { [23, p. } 31]\end{array}$ & $\begin{array}{l}\text { Outcomes and benefits are hard to } \\
\text { estimate / intangible yet an } \\
\text { informed debate on societal issues, } \\
\text { and rapid responses to } \\
\text { contingencies may prove to be } \\
\text { priceless [23, p. } 89,90] \text { promote } \\
\text { the safety and welfare of the } \\
\text { people [30] }\end{array}$ & $\begin{array}{l}\text { Uncertainties related } \\
\text { to information ethics, } \\
\text { legal barriers (in } \\
\text { particular intellectual } \\
\text { property rights) } \\
\text { Demarcation of } \\
\text { public domain } \\
\text { (versus commercial } \\
\text { sphere) [23, p. } 35]\end{array}$ \\
\hline & & $\begin{array}{l}\text { Civic and private } \\
\text { sector involvement } \\
{[25, \text { p. } 75]}\end{array}$ & $\begin{array}{l}\text { disasters have shown that current } \\
\text { information can save lives, and } \\
\text { protect public and private property } \\
\text { Best available data are often are } \\
\text { proprietary, or at the local, } \\
\text { municipal, or county government } \\
\text { level and are made available at } \\
\text { significant cost or with restrictions } \\
\text { (...) The greatest benefits will be } \\
\text { an enrichment of entire national } \\
\text { coverage. }\end{array}$ & $\begin{array}{l}\text { The greatest } \\
\text { challenges will be } \\
\text { coordination among } \\
\text { hundreds of } \\
\text { participants and } \\
\text { developing } \\
\text { incentives for state } \\
\text { and local } \\
\text { governments to share } \\
\text { and standardize their } \\
\text { data or metadata }\end{array}$ \\
\hline
\end{tabular}

Table 1: Summary of the American SDI Myth 1990-2007.

\subsection{The African myth 1999-2007}

On the African continent, the global sustainable development agenda converged in the first years of the new millennium with the pan-African 
information society initiative (AISI). The adoption of AISI by the African Union Heads of State Summit in July 1996, elevated AISI to an African "ICT constitution" of sorts, a regional framework to support the New Partnership for Africa's Development (NEPAD) and a mechanism for achieving the Millennium Development Goals (MDG). AISI called for the development of a national information and communication infrastructure (NICI) plan in every African country [36]. The AISI aims to realize by 2010 a sustainable information society in Africa where "information and decision-support systems are used to support decision-making in all the major sectors of the economy [...] access is available to international, regional and national 'information highways', providing 'off-ramps' in the villages [while] a vibrant business sector exhibits strong leadership capable of forging the build-up of the information society" [38].

The United Nations Economic Commission for Africa (ECA) was instrumental in the inception of AISI and the implementation of NICIs with support from other United Nation agencies and bilateral donors. In its effort to promote the economic and social development of the African Union, foster intra-regional integration, and promote international cooperation for Africa's development, ECA plays a critical role in helping build consensus around key African development challenges and in articulating common African perspectives and positions, which then form the basis for engagement with the international community. Its mandate and ability to convene senior policy makers, through ECA's annual Conference of Ministers of Finance, Planning and Economic Development and other development stakeholders, is pivotal in ensuring this role.

The AISI caused a reshuffling of ECA's own programmes including the launching of the Committee on Development Information (CODI), a subsidiary body of ECA, providing policy and technical guidance for the "harnessing information for development" programme. The programme's objective is to provide assistance to African governments in the fields of Spatial Data Infrastructure and National Information and Communication Infrastructure (NICI) development, under the umbrella of AISI. CODI has regularly convened voting delegates from African member states and international observers since 1999 in bi-annual conferences to discuss policy issues related to the implementation of AISI by the key players in the African communities of "geoinformation", "statistics", and "ICT".

The resolutions adopted in the five conferences of the CODI subcommittee on geoinformation to date, organized under the wings of the ECA, together with documents commissioned to consultants and endorsed or written by ECA can be read as Africa's hymn to SDI progress [3-7]. In the CODI proceedings, SDI is portrayed as embedding "raw materials", to be used for (1) sustainable development, (2) timely ("informed") decision making regarding food security, poverty alleviation, and environmental monitoring, and (3) the realization of overarching NEPAD objectives and Millennium Development Goals (see Table 2 for a more elaborate description). 


\begin{tabular}{|c|c|c|c|c|}
\hline$\underline{\text { Period }}$ & Metaphor & What is aimed for & Justification & Barriers \\
\hline \multirow[t]{3}{*}{$\begin{array}{l}1999- \\
2007\end{array}$} & \multirow[t]{3}{*}{$\begin{array}{l}\text { Raw material } \\
{[3,4]}\end{array}$} & \multirow{2}{*}{$\begin{array}{l}\text { Backbone for } \\
\text { sustainable } \\
\text { development as } \\
\text { well as decision } \\
\text { making regarding } \\
\text { food security, } \\
\text { poverty alleviation, } \\
\text { environmental } \\
\text { monitoring and } \\
\text { control and natural } \\
\text { resources } \\
\text { management [3] }\end{array}$} & $\begin{array}{l}\text { Critical need for timely } \\
\text { information for decision } \\
\text { making }[3, \text { p. } 4]\end{array}$ & $\begin{array}{l}\text { Lack of } \\
\text { resources at all } \\
\text { educational } \\
\text { levels }\end{array}$ \\
\hline & & & $\begin{array}{l}\text { Realization of NEPAD } \\
\text { objectives, Millennium } \\
\text { Development Goals and } \\
\text { WSSD }\end{array}$ & $\begin{array}{l}\text { Low awareness } \\
\text { of value of } \\
\text { spatial } \\
\text { information by } \\
\text { policy makers }\end{array}$ \\
\hline & & $\begin{array}{l}\text { Delivery of spatial } \\
\text { information to } \\
\text { widest possible } \\
\text { group of potential } \\
\text { users }\end{array}$ & & $\begin{array}{l}\text { Lack of } \\
\text { implementation } \\
\text { methodology }\end{array}$ \\
\hline \multirow[t]{4}{*}{$\begin{array}{l}1999- \\
2005\end{array}$} & \multirow[t]{4}{*}{$\begin{array}{l}\text { Information } \\
\text { Marketplace }\end{array}$} & & $\begin{array}{l}\text { Investment value and } \\
\text { national benefits of spatial } \\
\text { data }[3, \text { p. } 4]\end{array}$ & \multirow{4}{*}{$\begin{array}{l}\text { Low awareness } \\
\text { of the value of } \\
\text { information } \\
\text { (especially } \\
\text { spatial } \\
\text { information) by } \\
\text { government } \\
\text { policy makers } \\
\text { and senior } \\
\text { management. } \\
\text { Lack of } \\
\text { implementation } \\
\text { methodology }\end{array}$} \\
\hline & & & $\begin{array}{l}\text { Economic potential }[37, \mathrm{p} \text {. } \\
\text { 1] }\end{array}$ & \\
\hline & & & $\begin{array}{l}\text { Service delivery industries } \\
\text { that depend on location } \\
\text { and spatial knowledge will } \\
\text { benefit from reduced }\end{array}$ & \\
\hline & & & $\begin{array}{l}\text { transaction costs and will } \\
\text { be stimulated, leading to } \\
\text { more economic activity } \\
\text { [37] }\end{array}$ & \\
\hline \multirow[t]{2}{*}{$\begin{array}{l}2003- \\
2007\end{array}$} & \multirow[t]{2}{*}{$\begin{array}{l}\text { Evolving } \\
\text { phenomenon }\end{array}$} & \multirow{2}{*}{$\begin{array}{l}\text { Alignment of SDI } \\
\text { initiatives with } \\
\text { overarching AISI } \\
\text { initiatives (NICI) }\end{array}$} & $\begin{array}{l}\text { National, strategic and } \\
\text { financial need for sound } \\
\text { decision making }\end{array}$ & \multirow[t]{2}{*}{$\begin{array}{l}\text { No } \\
\text { implementation } \\
\text { methodology }\end{array}$} \\
\hline & & & $\begin{array}{l}\text { Fundamental geospatial } \\
\text { datasets are required for } \\
\text { informed decision making }\end{array}$ & \\
\hline
\end{tabular}

Table 2: Summary of the African SDI Myth 1990-2007.

If one reads the African tale as a myth to progress, the tale initially thrives on hymns to rationalized decision making in national single nation settings, but soon snowballs into rhetoric that addresses more complex objectives like poverty alleviation, food security, and natural resources management. Throughout the period covered in the analysis the cast of obstacles remains stable; in various 
CODI documents, as well as in auxiliary studies, there are continuous references to lack of resources, lack of awareness, and lack of support (in the sense of methodologies) to guide action. Use of imagery is restricted to occasional references to backbones for decision making regarding a host of abstract goals and to information markets.

The relative paucity of "content" in the African Tale is counterbalanced by its relative richness in "procedures". To counteract the high degree of heterogeneity (different forms of knowledge, different forms of governance, etc) in the African tale consensus could be reached only when a common platform has been agreed upon, in the shape of shared procedures of evidence [32]. The quest for "procedures" has been part of the solution suggested in the Down to Earth report ("developing countries should consider using a standardized SDI" [24]) and is the single most persisting feature of the African Tale. With no single source of information or instruction on how to proceed to set up a national spatial data infrastructure the quest for procedures resulted in three iterations:

- The compilation of a SDI Implementation guide for Africa [5] was attempted under the auspices of ECA as "guidelines on concrete steps to implement SDIs in Africa, targeted to all those that have a key role to play in promoting, adopting, developing or implementing spatial information infrastructure in their home countries" [4] and reinforced by appeals of representatives from member States, academia, professional bodies, and other sectors [30];

- During the actual compilation of the guide the practical difficulty of developing a "how to" step-by-step guide for something that defies computation was resolved by organizing the material of the SDI Implementation guide for Africa as "chess" moves and options [30];

- With progress still elusive in 2005, the third iteration portrayed African SDI as an AISI implementation tool, thus aligning SDI implementation procedures with the broader and successful NICI implementation procedures in Africa.

In November 2007, ECA published a report titled E-strategies: National Information and Communication Infrastructure (NICI): Best Practices and lessons learned [27]. In this report, African national SDI initiatives are reframed as "geoenabling the NICIs" [27] in an argumentative turn reminiscent of SDI piggybacking on II more than ten years earlier in North America. The report concludes that the "development, deployment and use of ICTs within the economy can contribute to and accelerate the socio-economic development process provided some critical success factors and conditions are addressed at all levels" [27]. Forty-five critical success factors and conditions are listed in [27], including good governance and rule of law, functioning democracy and democratic institutions, prevailing peace, national unity and national security, sub-regional stability and peace, and stable economic policy environment. The tautology suggested by these 
prerequisites - ICTs contribute to development, under the condition of development - is difficult to miss.

\section{Conclusions and future work}

In this chapter, we showed how the concept of SDI was developed, transformed, and translated in the North American context in which it was conceived, how it travelled to an African context, and how it was translated in that particular context over time. We used basic rhetorical analysis and the concept of myths to show how bricoleurs of the NRC (in North America) and CODI (in Africa) enact reality. Reflecting on Sahlin-Andersson's notions of imitation of ideas [34], a number of observations (and subsequent research directions) can be noted.

First, the CODI bricoleurs seem to have copied some of the metaphors of the more generalized North American SDI tale. The perceived obstacles remain constant, throughout the process and in the comparison between the North American tale and the African tale, with a number of usual suspects being (1) lack of resources, (2) lack of awareness, and (3) lack of incentives for governments and private sector corporations to enter into information partnerships.

Second, the "corrective turns" in the SDI rhetoric (responding to faltering progress) display how in the North American and in the African tales, myths are edited in specific ways to account for differences in institutional context, presumably in order to seek legitimacy for the idea of SDI. In the United States, emerging practices include the use of metrics, a focus on a single agency with a unique role, and knowledge generation through research. In Africa, the absence of a pan-African legislative SDI framework and research, paradoxically considered as luxury given the urgency of the challenges in Africa, lends a characteristic twist to the emerging "corrective" practices, while some uniformity with the rest is still evident. SDI metrics emerge again as a prominent practice, but this time subservient to a broader agenda — in the guise of NICI compliant implementation steps - and at a high political risk. Overall, what can be witnessed is that the SDI myth in North America is aligned with theory development and theory use in the clamour for best practices and demonstrated uses of SDI, whereas in Africa, SDI is interwoven with the political agenda of AISI and the NICI community.

All in all, the way the SDI - conceived as a myth - has been developed and translated in time and space shows that - in a yet unspecified way - it interacts with the context in which the myth takes shape. NICI and SDI discourses unfolded in Africa in a context marked by the overwhelming support to NEPAD, which signalled the ideological convergence of the ECA and the African Union with the neoliberal agenda of international financing institutions after decades of disagreement and acrimony between the "international community" and African leaders [31]. In order to identify core elements of the process of translation, future work has to focus on a number of issues. 
First, an obvious candidate for further exploration is the organisation field of foreign aid to Africa - a world-wide network populated by formal, "giving" and "taking", national and multinational organisations pursuing and financing development - in which translation takes place [33]. At least two intermediate spaces of the organisation field can be distinguished, a regional and a national one.

In the regional intermediate space, ECA and the Conference of Ministers of Finance, Planning and Economic Development articulate common African perspectives and positions, which form the basis for engagement (and further translation of these positions) with international financing institutions and bilateral donors. In the national intermediate space of a single country, ministries and other government and non-government organisations - arguably reconfigured to communicate with structures similar to those of the donors by a process of "contact infection" [14] - engage in a technical game. In this technical game, a seemingly impossible feat is attempted: the transfer of a "thing" - e.g. a water management system, a professional practice, a legal framework or an idea- from one context to the next in such a way that the "thing" remains identical while it is transformed to accomplish the desired impact in the destination context [33]. Second, further research should be directed to the micro processes of translation: of how myths, not in an abstract way, but in processes of bilateral and multilateral communication at conferences, in think tanks, etc., are edited, and are or are not vulnerable to varying degrees of professionalization of bodies, variety in cognitive, and technical skills, etc.

Myths serve as a link between argument and acceptance in intermediate spaces of the foreign aid organisation field and in micro processes of translation. In its composition, the myth may refer to resources such as legitimacy, power, skills, and money. These resources, however, are not simply available "out there", but are dispersed over the variety of organisations operating in the foreign aid field. Myths then are not only composed in a way that inspires action, but also in a way that enables translation and communication between developing countries and donors.

\section{References}

[1] Barzelay, M. \& Gallego, R. (2006). From "new institutionalism" to "institutional processualism": Advancing knowledge about public management policy change.. Governance, 19(4), 531-557.

[2] Bekkers, V.J.J.M. \& Homburg, V.M.F. (2007). The myths of e-government: Looking beyond the assumptions of a new and better government. The Information Society, 23(5), 373-382.

[3] CODI I (1999). Report of the first meeting of the committee on development information (CODI I): Harnessing information for development, Subcommittee on geoinformation 28 June - 2 July 1999. Addis Abeba: Economic Commission for Africa.

[4] CODI II (2001). Report of the second meeting of the committee on development information (CODI II): Development information and decision making, 
Subcommittee on geoinformation, 4 - 7 September 2001. Addis Abeba: Economic Commission for Africa.

[5] CODI III (2003). Report of the third meeting of the committee on development information (CODI II): Information and Governance, Subcommittee on Geoinformation, 10 - 13 May 2003. Addis Abeba: Economic Commission for Africa.

[6] CODI IV (2005). Report of the fourth meeting of the committee on development information (CODI IV): Information as an economic resource, Subcommittee on Geoinformation, 23 - 28 April 2005. Addis Abeba: Economic Commission for Africa.

[7] CODI V (2007). Report of the fifth meeting of the committee on development information (CODI V): Employment and the knowledge economy, Subcommittee on geoinformation, 29 April - 4 May 2007. Addis Abeba: Economic Commission for Africa.

[8] Czarniawska, B. \& Sevón, G. (2005). Global ideas: How ideas, objects and practices travel in the global economy. Copenhagen: Copenhagen Business School Press.

[9] Department of Science and Technology (2001). National spatial data infrastructure (NSDI) (Strategy and action plan). Bangalore: Task Force on NSDI, Department of Science and Technology.

[10] Fisher, F. \& Forrester, J. (eds.) (1993). The argumentative turn in policy analysis and planning. London: Routledge.

[11] Georgiadou, Y., Puri, S.K., \& Sahay, S. (2006). The rainbow metaphor: spatial data infrastructure organization and implementation in India. International studies of management and organization, 35(4), 48-71.

[12] Hood, C. \& Jackson, M. (1991). Administrative argument. Aldershot: Dartmouth.

[13] INSPIRE Directive (Joint Research Centre, E.C.E.I., Italy), (2007). Directive 2007/2/EC of the European Parliament and of the Council of 14 March 2007 establishing an infrastructure for spatial information in the European Community (INSPIRE). Published in the official Journal on the 25th April 2007.

[14] Kühl, S. (2005) Organisationen in der Weltgesellschaft: Zur Rolle der Entwicklungshilfe bei der Diffusion von Organisationen. Working paper 2, www.hsu-hh.de/download-1.4.1.php?brick_id=UGo1B67ZfyPIcU7N.

[15] Lévi-Strauss, C. (1987). Anthropology and myth: Lectures 1951-1982. New York: Blackwell Publishers.

[16] MacIntyre, A. (1970). Sociological theory and philosophical analysis. London: MacMillan Publishers.

[17] March, J.G. \& Olsen, J.P. (1989). Rediscovering institutions. New York: The Free Press.

[18] Masser, I. (2004) The future of spatial data infrastructures, in ISPRS Workshop on Service and Application of Spatial Data Infrastructure. Hangzhou, China.

[19] McLaughlin, J.D. (1991).Spatial data infrastructures: the next LIM challenge. Proceedings of the 1991 Conference on Land Information Management, (pp. 8-20), University of New South Wales, Australia: New South Wales, Australia.

[20] McLaughlin, J.D. (1991).Towards a national spatial data infrastructure. In Proceedings of the Canadian conference on GIS, (Ed.), (pp. 1-5), Canadian Institute of Geomatics: Ottawa, Canada.

[21] Mosco, V. (2004). The digital sublime: Myth, power and cyberspace. Cambridge: The MIT Press.

[22] National Research Council (1995). A data foundation for the national spatial data infrastructure. Washington DC: National Academy Press.

[23] National Research Council (1999). Distributed geolibraries: Spatial information resources. Washington DC: National Academic Press. 
[24] National Research Council (2002). Down to earth: Geographic information for sustainable development in Africa. Washington DC: National Academy Press.

[25] National Research Council (2001). National spatial data infrastructure partnership programs: Rethinking the focus. Washington DC: National Academy Press.

[26] National Research Council (1994). Promoting the national spatial data infrastructure through partnerships. Washington DC: National Academy Press.

[27] National Research Council (2007). A research agenda for Geographic Information Science at the United States Geological Survey. Washington, DC: National Academies Press.

[28] National Research Council (1990). Spatial data needs: The future of the national mapping program. Washington DC: National Academy Press.

[29] National Research Council (1993). Toward a coordinated spatial data Infrastructure for the nation. Washington DC: National Academy Press.

[30] National Research Council (2003). Weaving a national map: Review of the U.S. Geological Survey concept of The National Map. Washington DC: National Academies Press.

[31] Owusu, F. (2003). Pragmatism and the gradual shift from dependency to neoliberalism: The World Bank, African leaders and development policy in Africa. World Development, 31(10), 1655-1672.

[32] Rottenburg, R. (2006).Code-switching, or why a metacode is good to have. In B. Czarniawska and G. Sevón, (Eds), How ideas, objects and practices travel in the global economy (pp. 259-274), Copenhagen: Copenhagen Business Press.

[33] Rottenburg, R. (2002). Weithergeholte Fakten: Eine Parabel der Entwicklungshilfe. Stuttgart: Lucius \& Lucius.

[34] Sahlin-Andersson, K. (2002). National, international and transnational constructions of New Public Management. In T. Christensen and P. Laegreid, Eds), New Public Management: The transformation of ideas and practice), Ashgate: Aldershot.

[35] Smullen, A. (2007). Translating agency reform (rhetoric and culture in comparative perspective). Rotterdam: Erasmus University.

[36] United Nations Economic Commission for Africa (2007). African Information Society Initiative (AISI). An action framework to build Africa's Information and Communication Infrastructure. Addis Abeba: United Nations Economic Commission for Africa.

[37] United Nations Economic Commission for Africa (2001). The future orientation of geoinformation activities in Africa: A position paper, ECA/DISD/GEOINFO/DOC/01, Endorsed by the second meeting of the committee on development Information, development information services division (DISD). Addis Abeba: United Nations Economic Commission for Africa,.

[38] United Nations Economic Commission for Africa (2003). SDI implementation guide for Africa. Endorsed by the third meeting of the committee on development information. Addis Abeba: United Nations Economic Commission for Africa.

[39] US President (1993). Executive order 12864. United States Advisory Council on the national information infrastructure. Federal Register, 58, 179.

[40] US President (1994). Executive Order 12906 on national spatial data infrastructure. Federal Register, 59, 71. 